\title{
Mitochondrial quality control: from molecule to organelle
}

\author{
Alba Roca-Portoles ${ }^{1,2} \cdot$ Stephen W. G. Tait ${ }^{1}$
}

Accepted: 8 January 2021 / Published online: 29 March 2021

(c) The Author(s) 2021

\begin{abstract}
Mitochondria are organelles central to myriad cellular processes. To maintain mitochondrial health, various processes co-operate at both the molecular and organelle level. At the molecular level, mitochondria can sense imbalances in their homeostasis and adapt to these by signaling to the nucleus. This mito-nuclear communication leads to the expression of nuclear stress response genes. Upon external stimuli, mitochondria can also alter their morphology accordingly, by inducing fission or fusion. In an extreme situation, mitochondria are degraded by mitophagy. Adequate function and regulation of these mitochondrial quality control pathways are crucial for cellular homeostasis. As we discuss, alterations in these processes have been linked to several pathologies including neurodegenerative diseases and cancer.
\end{abstract}

Keywords Mitochondrial dysfunction · UPR ${ }^{\mathrm{mt}} \cdot \mathrm{ISR} \cdot$ Mitochondrial fission $\cdot$ Mitochondrial fusion · Mitophagy $\cdot$ PINK1 · Parkin · Mitochondrial diseases

\section{Introduction}

Mitochondria are implicated in an expanding array of biological processes including redox balance, calcium homeostasis, energy production, metabolism and cell death $[1,2]$. To maintain function, cells have evolved various processes that sense and respond to defective mitochondrial activity. These mechanisms react differently depending on the nature or intensity of the stress that mitochondria face. For instance, mitochondria can sense internal stresses such as misfolded proteins, mitochondrial DNA (mtDNA) mutations, metabolic or oxidative stress [3]. Mitochondria can adapt to these by retrograde signaling to the nucleus leading to the transcriptional upregulation of stress response proteins [4, 5]. Besides these stresses, mitochondria also face external ones such as mechanical stress, infection and environmental stress (e.g., hypoxia) [3]. Hence, when cells are challenged,

Alba Roca-Portoles

alba.roca@cbm.csic.es

Stephen W. G. Tait

stephen.tait@glasgow.ac.uk

1 Institute of Cancer Sciences, Cancer Research UK Beatson Institute, University of Glasgow, Switchback Road, Glasgow G61 1BD, UK

2 Present Address: Centro de Biología Molecular Severo Ochoa (CBMSO), Nicolás Cabrera, 1, 28049 Madrid, Spain mitochondria can maintain function through a second line of defense, by altering their mitochondrial dynamics. However, in the face of persistent damage, another homeostatic mechanism is to remove damaged mitochondria through a process called mitophagy $[3,6,7]$.

Alterations in mitochondrial quality control responses have been described in several mitochondrial diseases such as neurodegenerative diseases (Parkinson's, Alzheimer's and Huntington's disease) [8-11], cardiomyopathies [12], ocular diseases [13,14] and cancer [15-17], highlighting the importance of an adequate balance of these pathways for maintaining homeostasis.

In this review, we will discuss key mechanisms of mitochondrial quality control pathways. Due to the complexity and diversity of these pathways we have divided them into two broad areas: regulation at the molecular level (focusing on mitochondrial-to-nuclear communication) and regulation at the organelle level (including mitochondrial dynamics and mitophagy). Our discussion is not intended to be exhaustive, for instance, for in-depth discussion of the cellular response to ROS, NAD + (nicotinamide adenine dinucleotide) and calcium signaling, the reader is referred to recent, comprehensive reviews [18-20]. 


\section{Regulation of mitochondrial quality control at the molecular level}

Mitochondria are organelles of bacterial ancestry. Thus, mitochondria have their own genome (mtDNA) in the matrix, which is surrounded by the inner (IMM) and outer mitochondrial membrane (OMM). While mitochondria have their own genome, the vast majority of mitochondrial proteins are encoded in the nucleus [21] and therefore require import to maintain mitochondrial function [22]. Additionally, mitochondria also need to cope with oxidative stress. Therefore, to ensure homeostasis, mitochondria have developed several mechanisms to sense and respond to stress via nuclear communication. This mito-nuclear communication-also termed mitochondrial retrograde signaling or mitohormesis-is an evolutionary conserved process. It can be triggered by several stressors such as misfolded proteins, inhibition of the ETC, mitochondrial depolarization, nutrient deprivation and/or redox imbalances [23-27]. Hence, different pathways are involved in regulating mito-nuclear communication (Fig. 1).

\section{Mitochondrial retrograde response}

One of the first descriptions of mitochondrial retrograde signaling was made in the yeast Saccromyces cerevisiae, where the genes $R T G 1$ and $R T G 2$ were found to regulate the expression of the nuclear gene citrate synthase (CIT2) in response to alteration of mitochondrial function [28]. Stemming from this finding, Jia et al. described that the transcription factor involved in the regulation of CIT2 expression in yeast is a heterodimeric complex of $R \operatorname{tg} 1 p$ and $\operatorname{Rtg} 3 p$ proteins (Retrograde regulation protein 1 and 3 ) [29]. Recently, it has been shown that inhibition of protein import into mitochondria and consequently cytoplasmic accumulation of misfolded mitochondrial proteins caused global changes at the transcriptome and proteome levels [30]. This led to an increased expression of proteasome subunit and cytosolic chaperones and a decrease in oxidative phosphorylation (OXPHOS) proteins. However, these changes were regulated by different transcription factors; Hsf 1 and Rpn4 were involved in the upregulation of the proteasome and chaperones proteins; whilst the inactivation of the HAP complex led to a downregulation of OXPHOS proteins [30]. This study shows that there are multiple pathways that regulate mito-nuclear communication. Indeed, several mitochondrial signaling pathways that respond to inhibition of protein import have been recently described in yeast such as the unfolded protein response activated by mistargeting of proteins (UPR ${ }^{\mathrm{am}}$ ) [31], mitochondrial precursor over-accumulation stress (mPOS) [32], mitochondrial compromised protein import response (MitoCPR) [33] and
Fig. 1 Mitochondrial retrograde signaling. The mitochondrial integrated stress response $\left(\mathrm{ISR}^{\mathrm{mt}}\right.$ ) is regulated by phosphorylation of the elongation transcription factor eIF $2 \alpha$, which enhances the translation of ATF4. The kinases HRI and GCN2 phosphorylate eIF2 $\alpha$ (P-eIF2 $\alpha$ ) following a mitochondrial stress. In addition, the ISR is also part of the mitochondrial unfolded protein response $\left(\mathrm{UPR}^{\mathrm{mt}}\right)$, activated by misfolded mitochondrial proteins. Moreover, other mechanisms of mito-nuclear communication (mTORC, SIRT1, GPS2) are activated following changes in mitochondrial ROS, NAD, ATP/ ADP ratio, calcium $\left(\mathrm{Ca}^{2+}\right)$ or membrane potential $(\Delta \psi)$. Once the transcription factors ATF4, ATF5, ATF2 and/or GPS2 are in the nucleus, they regulate the expression of nuclear stressresponse genes

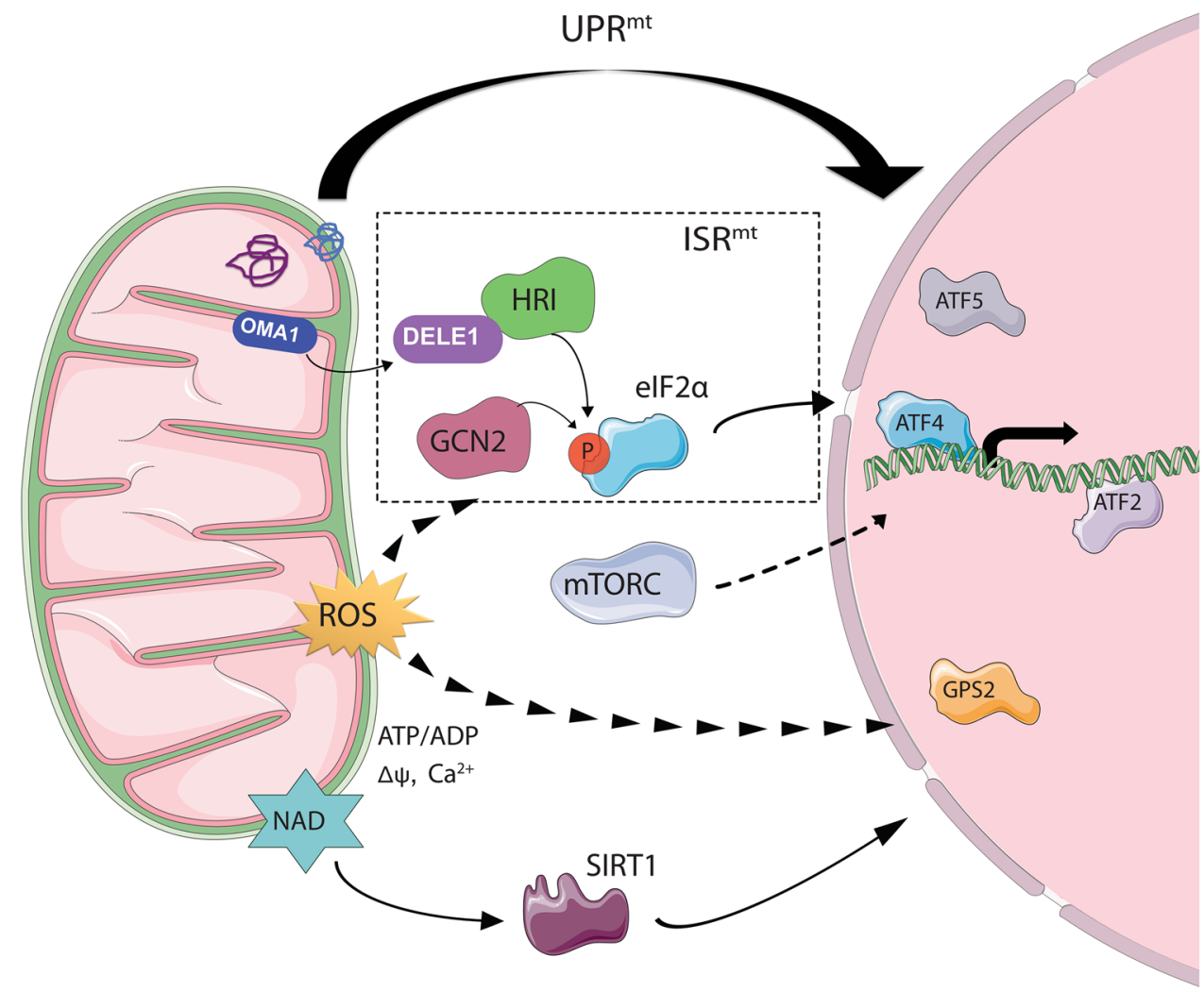


mitochondrial protein translocation-associated degradation (mitoTAD) [34], reviewed in [35].

Mitochondrial retrograde signaling has also been described in the nematode Caenorhabditis elegans, where mitochondria can sense and respond to unfolded proteins by activating the mitochondrial unfolded protein response $\left(\mathrm{UPR}^{\mathrm{mt}}\right)$, and thereby regulating the expression of mitochondrial chaperone genes, amongst others [36]. Mechanistically, Haynes and colleagues found that upon a proteotoxic stress, the mitochondrial matrix protease CLPP and the homeodomain-containing transcription factor DVE-1 in complex with the small ubiquitin-like protein UBL-5, are required for $\mathrm{UPR}^{\mathrm{mt}}$ [37]. Additionally, they found that both CLPP and the mitochondrial peptide transporter, HAF-1, are required for activation of the transcription factor ZC 376.7, which binds to and activates the expression of nuclear genes involved in the $\mathrm{UPR}^{\mathrm{mt}}$ [38]. The transcription factor ZC376.7 (mammalian homolog of ATF5), was later re-named as ATFS-1 (Activating Transcription Factor associated with Stress-1). Thus, Nargund et al. showed that in C. elegans, ATFS-1 is imported into mitochondria and degraded under basal conditions, but following a mitochondrial stress, ATFS-1 accumulates in the cytosol, promoting its nuclear transport [39]. In the nucleus, ATFS-1 regulates the expression of several nuclear genes involved in immunity, mitochondrial chaperones and metabolism, amongst others [40, 41].

Besides these, other complementary mitochondrial retrograde signaling pathways have been observed in worms in response to mitochondrial dysfunction and oxidative stress (ROS). For instance, the translation initiator factor eIF2 $\alpha$ (Eukaryotic Translation Initiation Factor 2A) is phosphorylated by the kinase CGN2 (general control non-derepressible-2) and modulates cytosolic protein synthesis [42]. On the other hand, the mitochondrial protein monooxygenase CLK-1 can translocate to the nucleus where it regulates ROS metabolism and proteostasis, by suppressing a subset of UPR ${ }^{\mathrm{mt}}$ genes [43]. Additionally, Herholz et al. found that Krüppel-like factor 1 (KLF-1) is the key transcription factor that regulates the expression of genes involved in xenobiotic detoxification processes [44]. This argues that distinct mechanisms are also involved in mito-nuclear communication in nematodes.

Furthermore, mitochondrial retrograde signaling has also been described in the fruit fly Drosophila melanogaster [45, 46] and in mammals. In mammals, there is evidence that treatments that alter mitochondria health, such as loss of membrane potential, unfolded proteins, inhibition of protein translation or mutations in mitochondrial DNA, signal to the nucleus in order to regulate the expression of nuclear genes and adapt towards adverse conditions [23-27]. Thus, indicating — as a generalized process—retrograde signaling is evolutionary conserved.
One of the mitochondrial retrograde signaling pathways in mammals is the UPR ${ }^{\mathrm{mt}}$, which, as in other species, is activated upon the accumulation of misfolded mitochondrial proteins. A similar mechanism has been previously documented in other mammalian organelles, notably the endoplasmic reticulum (ER), where three different pathways (ATF6, PERK, IRE1 $\alpha$ ) are known to regulate the endoplasmic reticulum unfolded protein response (UPR ${ }^{\mathrm{er}}$ ) [47]. Upon the discovery of UPR ${ }^{\mathrm{mt}}$ in other organisms, there has been intensive research trying to identify transcription factors involved in the mammalian UPR ${ }^{\mathrm{mt}}$. One possibility is the protein ATF5 (Activated Transcription Factor 5), that appears to be activated similarly to ATFS-1 [48], meanwhile others have reported ATF4 (Activated Transcription Factor 4) as the transcription factor activated upon mitochondrial stress [5]. In addition, there is also evidence in both nematodes and mammalian cells, that NAD + can activate the $\mathrm{UPR}^{\mathrm{mt}}$ through activation of the Sirtuin pathway (specifically SIRT1) [49].

Another mechanism involved in the mitochondrial retrograde signaling is the integrated stress response (ISR). This pathway is activated upon several stresses such as proteostasis defects, nutrient deprivation, redox imbalances and viral infection, amongst others. However, all of them converge in the phosphorylation of the translation initiator factor eIF2 $\alpha$ [50]. Various kinases that phosphorylate eIF $2 \alpha$ have been identified: the double-stranded RNA-activated protein kinase (PKR) [51, 52], the general control non-derepressible-2 (GCN2) [53], the endoplasmic reticulum (ER) resident kinase (PERK) [54] and heme-regulated inhibitor (HRI) [55]. Upon phosphorylation of eIF2 $\alpha$ (P-eIF2 $\alpha$ ), the activity of eIF2B (eIF2's guanine nucleotide exchange factor) is blocked, therefore inhibiting protein synthesis [56]. Nevertheless, P-eIF2 $\alpha$ can enhance the translation of the transcription factor ATF4 [57]. ATF4 was first described as a transcription factor involved in the UPR ${ }^{\mathrm{er}}$ upon activation by PERK [57]. Nevertheless, different studies have shown that eIF2 $\alpha$ and ATF 4 can be activated not only upon ER stress but also upon mitochondrial stress engaged by other signaling pathways [5, 42]. Two recent papers have described a mechanism of activation of ATF4 following a mitochondrial stress [58, 59]. Employing a genome-wide CRISPR screen, they found that OMA1 (a mitochondrial stress protease located on the inner mitochondrial membrane) is activated upon mitochondrial stress and cleaves DELE1 (another inner mitochondrial membrane protein). Cleavage of DELE1 leads to its accumulation in the cytosol and therefore activation of HRI, one of the kinases that phosphorylates eIF $2 \alpha[58,59]$.

Interestingly, the expression of not only ATF4 but also ATF5 is enhanced by eIF2 $\alpha$ [60], thereby indicating that activation of the ISR is required for activation of UPR ${ }^{\mathrm{mt}}$ in mammals. In addition, in muscle, mTORC1 has been shown to regulate the one carbon metabolism and metabolic 
cytokines (FGF21) via ATF4 signaling [61], indicating a role for mTORC1 also in the ISR. Furthermore, Cardamone and colleagues described that the protein GPS2, involved in inflammation and lipid homeostasis, regulate the transcription of several ISR regulated genes [62]. They found that this protein resides in the mitochondria and, upon mitochondrial depolarization induced by FCCP treatment (a mitochondrial uncoupler of oxidative phosphorylation that disrupts ATP synthesis); GPS2 translocates to the nucleus, upregulating the expression of nuclear genes involved in the tricarboxylic acid (TCA) cycle, the electron transport chain (ETC), lipid synthesis and interleukin signaling pathways [62].

Although less well-described, apart from these, other mechanisms of mitochondrial retrograde signaling have also been reported in mammals. For instance, in myocytes, different mitochondrial stressors (decrease in mitochondrial membrane potential, inhibition of electron transport chain, reduced mtDNA or increased intracellular calcium levels) caused alterations in the expression of nuclear genes. These nuclear genes were regulated by the transcription factors NFAT (cytosolic counterpart of activated T-cell-specific nuclear factor) and ATF2 (Activated transcription factor 2) [27].

In vivo studies have confirmed the existence of several mitochondrial stress pathways in mammals [63-65]. Thus, Gomes et al. showed that when nicotinamide mononucleotide adenylyltransferase (NMNAT1) was decreased in the nucleus, it caused a decrease in expression of mitochondrial OXPHOS genes, mtDNA and ATP levels, by activating SIRT1 [65]. Moreover, mice that lack the expression of the mitochondrial aspartyl-tRNA synthetase, DARS2 (DARS2-deficient mice) display deregulated mitochondrial protein synthesis and thereby activation of the $\mathrm{UPR}^{\mathrm{mt}}$ [64]. However, although these mice demonstrated alterations in the respiratory chain, activation of the mitochondrial stress response was independent of the respiratory defects observed [64]. Nevertheless, deletion of CLPP in DARS2deficient mice decreased the observed respiratory defects but did not rescue the $\mathrm{UPR}^{\mathrm{mt}}$ signaling, indicating a role of CLPP in OXPHOS regulation [63]. In addition, unlike in the nematode $C$. elegans where CLPP has a central role in regulating UPR ${ }^{\mathrm{mt}}$ [37], this study showed no role for CLPP in $\mathrm{UPR}^{\mathrm{mt}}$ regulation in mammals [63]. Hence, these data argue against different mitochondrial stress pathways involved in mito-nuclear communication in vivo that act cooperatively to maintain homeostasis.

\section{Mitochondrial retrograde signaling in health and disease}

Since the decline of mitochondria function is a hallmark of aging, neurogenerative disease and cancer [66], understanding how those pathways work is important for human health. In fact, several studies have demonstrated the importance of the $\mathrm{UPR}^{\mathrm{mt}}$ for development and longevity $[42,67]$. Thus, mutations or deletions in genes involved in the ETC [68] and increased levels of NAD + [49], activated the UPR ${ }^{\mathrm{mt}}$ and extended lifespan. How mito-communication regulates lifespan remains unclear. Gomes et al. demonstrated that SIRT1/HIF1 $\alpha$ pathway contributes to aging-associated mitochondrial dysfunction in mice and that this phenotype could be reversed by increasing NAD + levels [65]. This indicates that increasing the levels of NAD + could be beneficial and a possible treatment option for patients with mitochondrial diseases. Similarly, another strategy for treating these patients may be using PARP-1 inhibitors as PARP-1 (poly(ADP-ribose) polymerase-1) is a NAD + consuming enzyme. Indeed, treatment with PARP-1 inhibitors has been demonstrated to restore mitochondrial function [69]. On the other hand, others have suggested that activation of UPR ${ }^{\mathrm{mt}}$ extends longevity due to the induction of changes in chromatin structure through histone modifications [70]. In addition, a role for ROS in longevity has also been proposed [43, 46, 71], although others have shown that in mice, accumulation of mtDNA mutations that are associated with an aging phenotype and reduced lifespan, did not affect ROS levels [72]. Recently, a study has found that KLF-1 regulates longevity independently of the UPR ${ }^{\mathrm{mt}}$ but dependently on redox signaling [44]. Importantly, that extended longevity was due to the expression of xenobiotic detoxification genes such as cytochrome P450 oxidases (CYPs) [44], proposing CYPs as the key effectors of lifespan extension. However, whether or not the association between mitochondrial dysfunction and longevity is due to ROS, epigenetics or any other mechanisms remains unclear.

Alteration of mitochondrial stress-signaling pathways has also been dysregulated in cancer. For instance, in gastric cancer, cisplatin resistance was found to be due to upregulation of the cystine/glutamate antiporter (xCT) via ROS/ GCN2-eIF2 $\alpha$-ATF4 pathway [73]. In addition, other studies have shown that tumours upregulate the ISR as a means of chemoresistance. BRAF-mutated melanoma cells, acquire resistance to vemurafenib by GCN2/ATF4 activation [74] and overexpression of ATF5 conferred radioresistance in lung cancer cells [75] and in malignant glioma cells, ATF5 promoted survival through transcription of anti-apoptotic MCL-1 [76]. Although the involvement of mitochondria was not shown directly in these studies, they offer proof of principle that ISR can induce drug resistance. Recently, ATF4 has also been shown to be oncogenic; in Drosophila, activation of ATF4 induced a Warburg-like phenotype and consequently tumorigenic growth [77] and in MYC-driven tumours, deletion of ATF4 prolonged survival [17], indicating that ATF4 is necessary for tumorigenesis. Collectively, although several advances have been made over 
the recent years in understanding the mitochondrial retrograde response in several organisms, much remains to be elucidated.

\section{Regulation of mitochondrial quality control at the organelle level}

As dynamic organelles, mitochondria can also alter their morphology by undergoing mitochondrial fission or fusion and thereby adapt toward stresses and fulfill the cellular needs. However, if the stress is severe or prolonged, cells can eliminate mitochondria through a process called mitophagy. Both mitochondrial dynamics and mitophagy, have demonstrated their importance for homeostasis as alterations in genes involved in these processes have been found in several diseases $[10,13,14,78]$.

\section{Mitochondrial dynamics}

Mitochondria are dynamic organelles that adapt their network according to cellular requirements. These changes are determined by rates of fission and fusion, the regulation of which varies with regards to the severity of the stresses that they face. Upon a high or prolonged stress, mitochondria undergo fission, meanwhile, upon a mild or low stress, mitochondria favour fusion [79]. Furthermore, studies have shown that mitochondria can also alter their morphology

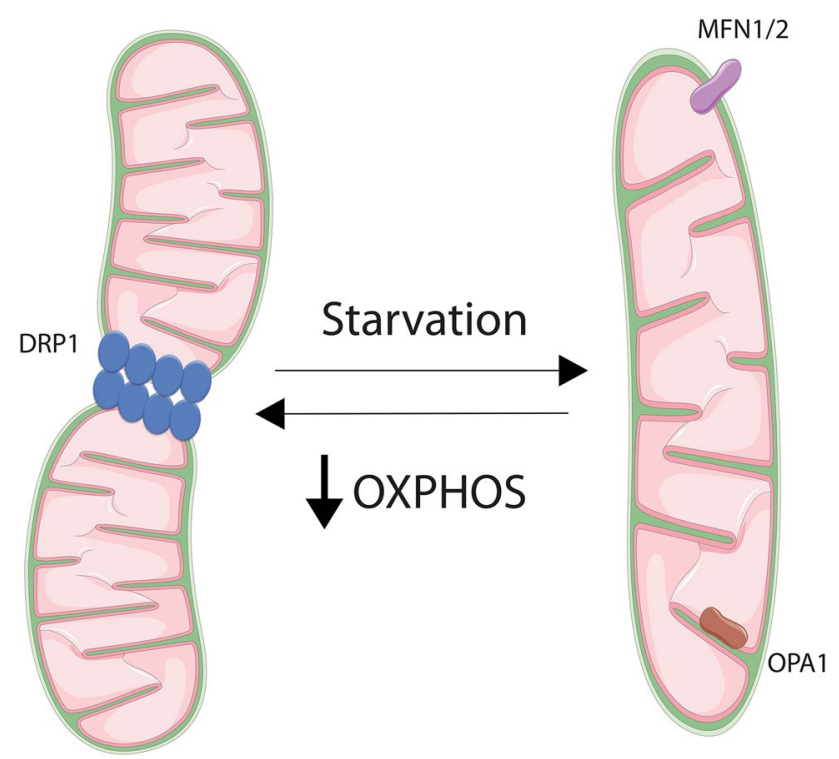

Fig. 2 Mitochondrial dynamics. Mitochondria are dynamic organelles that adapt their network according to cellular requirements. For instance, a decrease of respiration leads to mitochondrial fission and starvation induces fusion. Both processes are regulated by different proteins; dynamin-related protein 1 (DRP1) is involved in fission, meanwhile Mitofusin 1 and Mitofusin 2 (MFN1/2) and optic atrophy 1 (OPA1) allows fusion. OXPHOS = oxidative phosphorylation depending on the nature of stress; starvation induces fusion, meanwhile, low glucose and ETC inhibition can induce fission [80-83] (Fig. 2).

An appropriate balance in mitochondrial dynamics is important for mitochondrial health as each of them is implicated in different processes. Fusion is involved in the maintenance of mtDNA integrity, mitochondrial respiration, mitochondrial membrane potential, apoptosis and calcium signalling [84-89]. Fission has been shown to be important for preventing oxidative damage and to enable degradation of damaged mitochondria [6, 87, 90]. Additionally, mitochondrial dynamics have also been implicated in life span regulation [91].

Mitochondrial fusion Mitochondrial fusion is regulated at both mitochondrial membranes; the outer membrane (OMM) and the inner membrane (IMM). Mitofusin 1 (MFN1) and Mitofusin 2 (MFN2) are GTPases required to allow fusion of the OM [92, 93] by forming homodimers or heterodimers [94]. This process is essential for development because combined knockout of MFN1 and MFN2 leads to embryonic lethality. Single knockouts of MFN1 or MFN2 are viable, however, deletion of each one alone promotes mitochondrial fragmentation, demonstrating their role in mitochondrial fusion [94]. In addition, mutations in MFN2 have been found in axonal Charcot-Marie-Tooth disease type 2A [9] and mice with the mutation R95Q in MFN2 developed this pathology [78]. MFN2 deficient mice showed cerebellar defects; dysfunctional ETC and loss of mtDNA nucleoids in Purkinje cells due to dysfunctional mitochondria (fusion-deficient cells) [95]. In another study, MFN2 mutant mice demonstrated a decrease in locomotive activity and a lack of MFN2 in dopaminergic neurons displayed fragmented mitochondria and decreased mitochondrial motility [96]. These data emphasise the importance of this protein and mitochondrial fusion for neurological development.

The protein optic atrophy 1 (OPA1) mediates fusion of the mitochondrial inner membrane [97, 98]. OPA1 has multiple isoforms due to splicing or variants generated via proteolytic cleavage. The long form of OPA1 (L-OPA1) is anchored in the inner membrane and it promotes mitochondrial fusion, whereas the short form of OPA1 (S-OPA1) is soluble. Mitochondrial fusion depends on the presence of both isoforms [99], by forming oligomeric complexes that maintain the cristae structure $[100,101]$. Cleavage of L-OPA1 into S-OPA1 is mediated by the AAA-proteases OMA1 [102, 103] and YME1L [99, 104, 105]. Stresses that activate OMA1 or YME1L, for instance loss of mitochondrial potential or OXPHOS activity, lead to the proteolytic process of L-OPA1 into S-OPA1, liberating this protein from the IMM and therefore promoting fission [99, 103, $106,107]$. Thus, regulation of OPA 1 proteolysis is a key 
process for mitochondrial network maintenance and function. Accordingly, mutations in this gene cause dominant optic atrophy (ADOA) $[13,14]$ and heterozygous mutations have been also associated with Behr syndrome [108].

Mitochondrial fission The main proteins involved in mitochondrial fission are DRP1 (dynamin-related protein 1) [109], mitochondrial fission factor (MFF) [110] and mitochondrial fission protein 1 (FIS1) [111], amongst others [112]. DRP1 is a GTPase that resides in the cytosol. Upon specific stimulus DRP1 is recruited onto the OMM by receptors such as MFF and FIS1 [110]. However, there are differences between the yeast FIS1 and the human Fis1 (hFis1) in their activity. A recent study has shown that hFis1 induces fission independently of DRP1, instead, hFis1 negatively regulates fusion by binding to OPA1, MFN1 and MFN2 and blocking its activity [113]. Nevertheless, once DRP1 gets onto the OMM it multimerizes and forms rings on the mitochondrial outer membrane [109]. Once there, by hydrolysing GTP, the complex changes conformation and allows the constriction of the membrane inducing its division [114]. DRP1 activity is not only regulated by its translocation, but also by post-translational modifications including phosphorylation, ubiquitylation, and SUMOylation. Phosphorylation of S616 allows DRP1 activity [115], meanwhile, phosphorylation of S637 and S656 inhibits it [116, 117]. However, several kinases have been involved in the phosphorylation of its residues. For instance, ERK1/2 [15, 118] and mitotic kinase cyclin B-CDK1 (cyclin-dependent kinase 1 [115] have been described to phosphorylate DRP1 in S616 [119]. On the other hand, S656 is phosphorylated by cyclic AMPdependent protein kinase, PKA, and dephosphorylated by calcineurin [117].

DRP1 is essential for development; whole-body deletion of DRP1 is embryonic lethal [120,121], showing the relevance of this protein for mitochondrial homeostasis. However, unlike MFN1/2 or OPA1, no autosomal diseases have been linked to mutations in DRP1, although alterations in mitochondrial fission have been related to neurodegenerative diseases [8]. Moreover, in different tumour models, such as pancreas [16], melanoma [118], lung cancer [122] and ovarian cancer [123], DRP1 and mitochondrial fission have shown to be important for tumour growth [15]. In addition, tissues from Alzheimer's disease (AD) [124] and Huntington's disease (HD) [125] patients demonstrated increased expression of DRP1 and FIS1, and decreased expression of MFN1, MFN2 and OPA1, indicating that an impairment on mitochondrial dynamics are associated with $\mathrm{AD}$ and $\mathrm{HD}$. Thus, an adequate function of mitochondrial fusion and fission is important for homeostasis and alterations in these processes are associated with several pathologies, such as cancer, neurodegenerative, neuroinflammatory and autoimmune disease [126].

\section{Mitophagy}

Autophagy is a regulated process through which cells can degrade unnecessary or non-functional cytosolic components through their engulfment in a double membrane vesicle, called autophagosome, and their delivery into the lysosomes. There are different types of autophagy such as macroautophagy, microautophagy, and chaperone-mediated autophagy (Reviewed in [127, 128]). The selective removal of mitochondria by autophagy, namely mitophagy, helps maintain adequate cellular homeostasis through the elimination of damaged mitochondria [7, 129] (Fig. 3). How was mitophagy discovered? Dysfunctional mitochondria were first observed inside vacuoles in yeast [130]. Later, the term mitophagy was coined by Lemaster's group after finding mitochondria inside of lysosomes in rat hepatocytes upon nutrient deprivation [131]. These observations raised several questions - how do cells sense damaged mitochondria and how is mitophagy regulated? There are many mechanisms of mitophagy described [132-136]. For instance, the protein NIX has been shown to be involved in the removal of nondamaged mitochondria during erythropoiesis [137, 138]. Here we will focus on the PINK1/Parkin pathway, as the

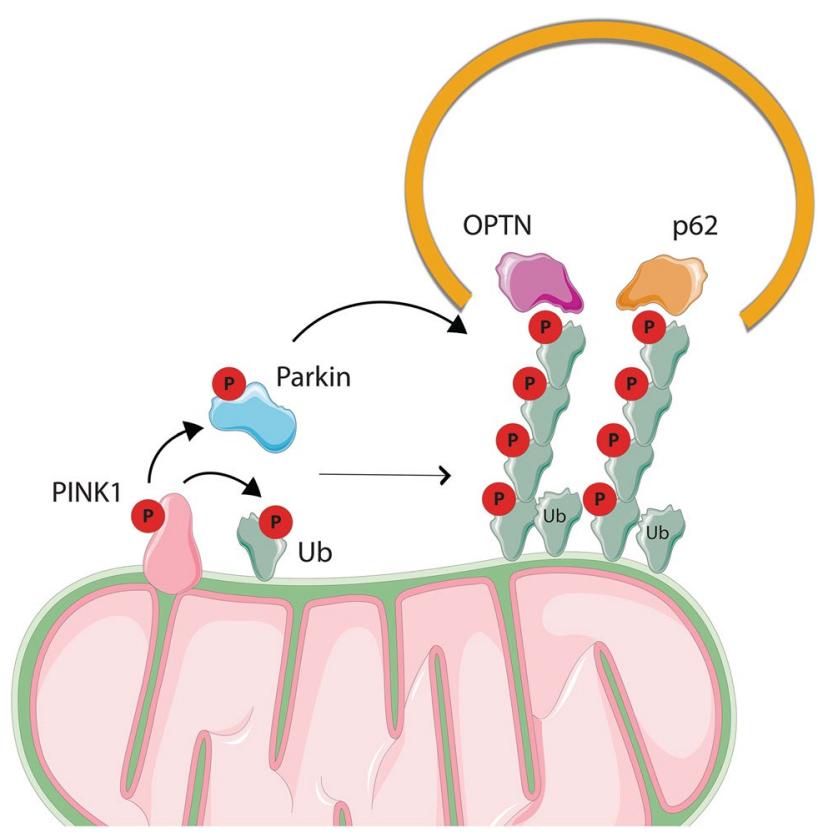

Fig. 3 Mitophagy. Mitophagy allows the removal of damaged mitochondria by the PINK/Parkin pathway. When mitochondria are damaged, PINK1 is accumulated on the outer mitochondrial membrane (OMM) where it gets activated and phosphorylates and therefore activates Ubiquitin (Ub) and Parkin. Parkin ubiquitinates different OMM proteins in a feed-forward mechanism, leading to a general mitochondrial ubiquitination. That ubiquitination recruits autophagy receptor proteins (OPTN, p62), and, in turn, autophagosomes into the mitochondria, leading to the induction of autophagy 
mechanism is better described and this pathway is involved in regulating mitochondrial stress response.

PINK1/Parkin pathway The importance of PINK1 (PTENinduced putative kinase 1) and Parkin for mitochondrial homeostasis is supported by the accumulation of dysfunctional mitochondria in Parkinson's disease (PD) models and patients $[10,139]$. In fact, both of these proteins have been found mutated in this disease; PINK1 mutation causes Hereditary Early-Onset Parkinson [10] meanwhile mutations in Parkin occurs in Autosomal recessive juvenile Parkinsonism (AR-JP) [11]. In Drosophila, studies have shown that this pathway is needed for maintaining adequate mitochondria function in muscle and neurons, and loss of function mutations of both proteins mimic the characteristic of PD [140]. Furthermore, in mice, deletion of Parkin leads to loss of dopaminergic neurons (DA), which is a hallmark of PD [141].

Under normal conditions, PINK1 is partially imported into mitochondria, where it is cleaved by the IMM protease PARL. This cleavage enables PINK1 ubiquitination and proteasome-dependent degradation in the cytosol [142]. Therefore, in healthy mitochondria, the levels of PINK1 are low in cells. Upon stresses such as mitochondrial depolarization [143], impairment of protein import [144], and others [145-147], PINK1 import into mitochondria is blocked and as a result, it accumulates on the OMM [148]. Once there, it binds the mitochondrial TOM complex $[149,150]$ and it is activated by auto-phosphorylation. Its activation leads to a signaling cascade by recruiting and activating other proteins like Parkin $[143,151]$ and Ubiquitin (Ub) [152]. Parkin is an E3 ubiquitin ligase that is activated upon PINK1 phosphorylation in its UBL domain $[153,154]$ and binding of phospho-Ub [152, 155-158]. Once activated, Parkin ubiquitinates different OMM proteins in a feed-forward mechanism, leading to a general mitochondrial ubiquitination. Then, receptor proteins on the mitochondria recruit the autophagic machinery which results in the engulfment of mitochondria by autophagosomes. Different autophagy receptors have been shown to play a role in mitophagy such as NDP52, optineurin (OPTN) and p62 [159, 160].

In vivo, the role of PINK1 and Parkin in mitochondrial homeostasis (mitophagy) is unclear. On the one hand, using a mouse model that lacks the proofreading function of the mitochondrial DNA polymerase g (POLG) (called Mutator mice), Pickrell and colleagues demonstrated that Parkin protects dopaminergic neurons from mitochondrial dysfunction. They show that Parkin loss in Mutator mice led to DA neuron loss and decrease in OXPHOS activity [161], thereby suggesting that Parkin has a role in maintaining mitochondrial homeostasis in vivo, or at least in DA neurons. On the other hand, mice that lack Parkin present normal cardiac function and their mitochondrial activity was unaltered. However, when those mice are challenged with a mitochondrial stress such as myocardial infarction or hypoxia, Parkin played a critical role in removing damaged mitochondria [162]. In line with these findings, another study has corroborated that in heart, the expression of Parkin is dispensable for mitophagy under basal conditions [163]. However, it contributes to mitochondrial removal in cardiomyopathies that present defects in mitochondrial fission [163], thus indicating a role of Parkin in regulating stress-induced mitophagy. In fact, studies have also shown that mice with PINK1 loss display normal basal mitophagy [135] and research in Drosophila has corroborated that under basal mitophagy, PINK1 and Parkin are dispensable [164]. Therefore, these studies together will indicate that the PINK1/Parkin pathway may not be implicated in regulating mitophagy under physiological conditions and/or that there are other additional pathways that regulate mitophagy [135]. In addition, although Parkin deficient mice demonstrated no role of Parkin for basal mitophagy, the mitochondria of those mice, although functional, were smaller [162], which may indicate that Parkin has additional roles independently of mitophagy. In fact, Parkin has also been involved in regulating bioenergetics [129], necroptosis [165], mitochondrial protein import [166], mitochondrial biogenesis [167] and inflammation [168].

Another question that remains controversial is whether PD is due to PINK1 or Parkin deficiency or due to a general mitochondrial dysfunction. The aforementioned study demonstrates a role of Parkin and PD [161]. However, pathogenic mutations of PD (T415N and G430D) that abolish the E3 activity of Parkin, altered its mitochondrial localization, whereas other pathological mutations (D280N or G328E) that do not alter its E3 activity did not impact Parkin recruitment to mitochondria [169]. In addition, mutations in PINK1 and Parkin are not exclusive for this pathology as other alterations such as mtDNA mutations [170, 171] and LRRK2 mutations [172, 173] have been described. Moreover, in some PD patients, impairment of MIRO1 degradation, an OMM protein that anchors mitochondria to microtubule motors, has also been observed [174]. Finally, another challenge of studying mitophagy is finding a physiological method of triggering it. Recently, Kovalchuke and colleagues have demonstrated that other more physiological oxidative stressors like L-DOPA, lead to Parkin degradation. Although the exact mechanism of how Parkin is degraded following L-DOPA remains unclear, they show that PINK1 and phospho-Ub are involved in this pathway [175], demonstrating a similar mechanism to other mitochondrial stressors such as CCCP (mitochondrial uncoupler) [156]. This study suggests that oxidative stress or phospho-Ub may contribute to the loss of Parkin in PD. Moreover, that finding opens a new strategy to treat those patients by blocking the association of Parkin with phospho-Ub. Another possible approach 
for PD treatment comes from the finding that PINK1 is cleaved by OMA1 in depolarised mitochondria. This indicates that inhibition of OMA1 could be used to increase the levels of mitophagy in PD patients [150].

To conclude, mitochondrial damage and defects in mitophagy have been observed in several neurodegenerative diseases, such as Parkinson's (PD) [176] Alzheimer's (AD) and Huntington's disease (HD) [177]. Moreover, mitophagy impairment has also been associated with myopathies, metabolic disorders, inflammation and cancer [178]. Therefore, it is important to understand the mechanisms behind it and its role in the diseases, as it will help to develop new approaches for improved treatments.

\section{Conclusion}

Although the UPR ${ }^{\mathrm{mt}}$ is mainly caused by protein misfolding [26], other stresses have also been found to activate the UPR ${ }^{\mathrm{mt}}$ [179]. In addition, several conditions that were found to activate the ISR such as alteration of mitochondrial membrane potential, mitochondrial respiration, block in mitochondrial translation or in mitochondrial protein import [5], also alter mitochondrial dynamics [80, 180] and/ or activated mitophagy [143, 144]. It is likely that activation of those pathways depends on the severity or duration of the stress. However, even though a threshold may exist, a connection between UPR $^{\mathrm{mt}}$ and mitophagy has been reported [144]. Similarly, studies have also demonstrated a relation between mitochondrial dynamics and PINK or mitophagy $[181,182]$. Therefore, these studies, amongst others, suggest a connection between the mitochondrial quality pathways, which requires further investigation.

As discussed, imbalances in quality control pathways have been associated with multiple pathologies. For instance, aberrations in mitochondrial dynamics have been found in cancer patients $[15,16]$, neurodegenerative diseases $[8,9]$ and ocular diseases [13, 14]. In addition, mutations in mitophagy-related genes have also been reported in neurodegenerative pathological conditions $[10,11]$. All these patients have alterations in mitochondrial morphology and function. However, these patients also present mutations in other genes [183], thereby is still unclear whether the development of the diseases is due to alterations in mitophagy itself or rather a general mitochondrial dysfunction. Alterations in the expression of proteins involved in mitochondrial retrograde signaling (ISR) have also been linked to resistance and tumour growth $[17,73,74,77]$. Hence, even though in the recent years new findings have given some clarity in understanding the mitochondrial quality control pathways, some mechanisms underlying mitochondrial homeostasis remain still unclear. Therefore, investigation of those pathways should provide knowledge for understanding, and potentially treating, mitochondrial pathologies.

Open Access This article is licensed under a Creative Commons Attribution 4.0 International License, which permits use, sharing, adaptation, distribution and reproduction in any medium or format, as long as you give appropriate credit to the original author(s) and the source, provide a link to the Creative Commons licence, and indicate if changes were made. The images or other third party material in this article are included in the article's Creative Commons licence, unless indicated otherwise in a credit line to the material. If material is not included in the article's Creative Commons licence and your intended use is not permitted by statutory regulation or exceeds the permitted use, you will need to obtain permission directly from the copyright holder. To view a copy of this licence, visit http://creativecommons.org/licenses/by/4.0/.

\section{References}

1. Nunnari J, Suomalainen A (2012) Mitochondria: in sickness and in health. Cell 148(6):1145-1159. https://doi.org/10.1016/j.cell. 2012.02.035

2. Bock FJ, Tait SWG (2019) Mitochondria as multifaceted regulators of cell death. Nat Rev Mole Cell Biol 21(2):85-100

3. Eisner V, Picard M, Hajnoczky G (2018) Mitochondrial dynamics in adaptive and maladaptive cellular stress responses. Nat Cell Biol 20(7):755-765. https://doi.org/10.1038/s41556-018-0133-0

4. Chandel NS (2014) Mitochondria as signaling organelles. BMC Biol 12:34-34. https://doi.org/10.1186/1741-7007-12-34

5. Quirós PM, Prado MA, Zamboni N, Damico D, Williams RW, Finley D, Gygi SP, Auwerx J (2017) Multi-omics analysis identifies ATF4 as a key regulator of the mitochondrial stress response in mammals. J Cell Biol 216(7):2027-2045

6. Youle RJ, Van Der Bliek AM (2012) Mitochondrial fission, fusion, and stress. Science 337(6098):1062-1065

7. Ashrafi G, Schwarz TL (2013) The pathways of mitophagy for quality control and clearance of mitochondria. Cell Death Differ 20(1):31-42

8. Costa V, Giacomello M, Hudec R, Lopreiato R, Ermak G, Lim D, Malorni W, Davies KJ, Carafoli E, Scorrano L (2010) Mitochondrial fission and cristae disruption increase the response of cell models of Huntington's disease to apoptotic stimuli. EMBO Mole Med 2(12):490-503

9. Bienfait HME, Baas F, Koelman JHTM, de Haan RJ, van Engelen BGM, Gabreëls-Festen AAWM, Ongerboer de Visser BW, Meggouh F, Weterman MAJ, De Jonghe P, Timmerman V, de Visser M (2007) Phenotype of charcot-marie-tooth disease type 2. Neurology 68(20):1658-1667. https://doi.org/10.1212/01.wnl. 0000263479.97552 .94

10. Valente EM, Abou-Sleiman PM, Caputo V, Muqit MMK, Harvey K, Gispert S, Ali Z, Del Turco D, Bentivoglio AR, Healy DG, Albanese A, Nussbaum R, Gonzalez-Maldonado R, Deller T, Salvi S, Cortelli P, Gilks WP, Latchman DS, Harvey RJ, Dallapiccola B, Auburger G, Wood NW (2004) Hereditary earlyonset Parkinson's disease caused by mutations in PINK1. Science (New York, N Y ) 304(5674):1158-1160

11. Kitada T, Asakawa S, Hattori N, Matsumine H, Yamamura Y, Minoshima S, Yokochi M, Mizuno Y, Shimizu N (1998) Mutations in the parkin gene cause autosomal recessive juvenile parkinsonism. Nature 392(6676):605-608

12. Song M, Mihara K, Chen Y, Scorrano L, Dorn GW 2nd (2015) Mitochondrial fission and fusion factors reciprocally orchestrate mitophagic culling in mouse hearts and cultured fibroblasts. Cell 
Metab 21(2):273-286. https://doi.org/10.1016/j.cmet.2014.12. 011

13. Alexander C, Votruba M, Pesch UE, Thiselton DL, Mayer S, Moore A, Rodriguez M, Kellner U, Leo-Kottler B, Auburger G (2000) OPA1, encoding a dynamin-related GTPase, is mutated in autosomal dominant optic atrophy linked to chromosome $3 \mathrm{q} 28$. Nat Genet 26(2):211

14. Delettre C, Lenaers G, Griffoin J-M, Gigarel N, Lorenzo C, Belenguer P, Pelloquin L, Grosgeorge J, Turc-Carel C, Perret E (2000) Nuclear gene OPA1, encoding a mitochondrial dynaminrelated protein, is mutated in dominant optic atrophy. Nat Genet 26(2):207

15. Kashatus JA, Nascimento A, Myers LJ, Sher A, Byrne FL, Hoehn KL, Counter CM, Kashatus DF (2015) Erk2 phosphorylation of Drp1 promotes mitochondrial fission and MAPK-driven tumor growth. Mol Cell 57(3):537-551

16. Nagdas S, Kashatus JA, Nascimento A, Hussain SS, Trainor RE, Pollock SR, Adair SJ, Michaels AD, Sesaki H, Stelow EB (2019) Drp1 promotes KRas-driven metabolic changes to drive pancreatic tumor growth. Cell Rep 28(7):1845-1859. e1845

17. Tameire F, Verginadis II, Leli NM, Polte C, Conn CS, Ojha R, Salas Salinas C, Chinga F, Monroy AM, Fu W, Wang P, Kossenkov A, Ye J, Amaravadi RK, Ignatova Z, Fuchs SY, Diehl JA, Ruggero D, Koumenis C (2019) ATF4 couples MYC-dependent translational activity to bioenergetic demands during tumour progression. Nat Cell Biol 21(7):889-899. https://doi.org/10.1038/ s41556-019-0347-9

18. Shadel GS, Horvath TL (2015) Mitochondrial ROS signaling in organismal homeostasis. Cell 163(3):560-569

19. Boyman L, Karbowski M, Lederer WJ (2020) Regulation of mitochondrial ATP production: $\mathrm{Ca} 2+$ signaling and quality control. Trends Mol Med 26(1):21-39

20. Canto C, Menzies KJ, Auwerx J (2015) NAD+ metabolism and the control of energy homeostasis: a balancing act between mitochondria and the nucleus. Cell Metab 22(1):31-53

21. Adams KL, Palmer JD (2003) Evolution of mitochondrial gene content: gene loss and transfer to the nucleus. Mol Phylogenet Evol 29(3):380-395. https://doi.org/10.1016/s1055-7903(03) 00194-5

22. Chacinska A, Koehler CM, Milenkovic D, Lithgow T, Pfanner $\mathrm{N}$ (2009) Importing mitochondrial proteins: machineries and mechanisms. Cell 138(4):628-644. https://doi.org/10.1016/j. cell.2009.08.005

23. Michel S, Canonne M, Arnould T, Renard P (2015) Inhibition of mitochondrial genome expression triggers the activation of CHOP-10 by a cell signaling dependent on the integrated stress response but not the mitochondrial unfolded protein response. Mitochondrion 21:58-68. https://doi.org/10.1016/j.mito.2015. 01.005

24. Moisoi N, Klupsch K, Fedele V, East P, Sharma S, Renton A, Plun-Favreau H, Edwards RE, Teismann P, Esposti MD, Morrison AD, Wood NW, Downward J, Martins LM (2009) Mitochondrial dysfunction triggered by loss of HtrA2 results in the activation of a brain-specific transcriptional stress response. Cell Death Differ 16(3):449-464. https://doi.org/10.1038/cdd. 2008.166

25. Martinus RD, Garth GP, Webster TL, Cartwright P, Naylor DJ, Hoj PB, Hoogenraad NJ (1996) Selective induction of mitochondrial chaperones in response to loss of the mitochondrial genome. Eur J Biochem 240(1):98-103. https://doi.org/10.1111/j.14321033.1996.0098h.x

26. Zhao Q, Wang J, Levichkin IV, Stasinopoulos S, Ryan MT, Hoogenraad NJ (2002) A mitochondrial specific stress response in mammalian cells. EMBO J 21(17):4411-4419. https://doi.org/ 10.1093/emboj/cdf445
27. Biswas G, Adebanjo OA, Freedman BD, Anandatheerthavarada HK, Vijayasarathy C, Zaidi M, Kotlikoff M, Avadhani NG (1999) Retrograde Ca2+ signaling in C2C12 skeletal myocytes in response to mitochondrial genetic and metabolic stress: a novel mode of inter-organelle crosstalk. EMBO J 18(3):522-533. https://doi.org/10.1093/emboj/18.3.522

28. Liao X, Butow RA (1993) RTG1 and RTG2: two yeast genes required for a novel path of communication from mitochondria to the nucleus. Cell 72(1):61-71. https://doi.org/10.1016/00928674(93)90050-Z

29. Jia Y, Rothermel B, Thornton J, Butow RA (1997) A basic helixloop-helix-leucine zipper transcription complex in yeast functions in a signaling pathway from mitochondria to the nucleus. Mol Cell Biol 17(3):1110-1117. https://doi.org/10.1128/mcb. 17.3.1110

30. Boos F, Kramer L, Groh C, Jung F, Haberkant P, Stein F, Wollweber F, Gackstatter A, Zoller E, van der Laan M, Savitski MM, Benes V, Herrmann JM (2019) Mitochondrial proteininduced stress triggers a global adaptive transcriptional programme. Nat Cell Biol 21(4):442-451. https://doi.org/10.1038/ s41556-019-0294-5

31. Wrobel L, Topf U, Bragoszewski P, Wiese S, Sztolsztener ME, Oeljeklaus S, Varabyova A, Lirski M, Chroscicki P, Mroczek S (2015) Mistargeted mitochondrial proteins activate a proteostatic response in the cytosol. Nature 524(7566):485-488

32. Wang X, Chen XJ (2015) A cytosolic network suppressing mitochondria-mediated proteostatic stress and cell death. Nature 524(7566):481-484

33. Weidberg H, Amon A (2018) MitoCPR-A surveillance pathway that protects mitochondria in response to protein import stress. Science 360(6385):10-19

34. Mårtensson CU, Priesnitz C, Song J, Ellenrieder L, Doan KN, Boos F, Floerchinger A, Zufall N, Oeljeklaus S, Warscheid B (2019) Mitochondrial protein translocation-associated degradation. Nature 569(7758):679-683

35. Boos F, Labbadia J, Herrmann JM (2020) How the mitoproteininduced stress response safeguards the cytosol: a unified view. Trends Cell Biol 30(3):241-254

36. Yoneda T, Benedetti C, Urano F, Clark SG, Harding HP, Ron D (2004) Compartment-specific perturbation of protein handling activates genes encoding mitochondrial chaperones. J Cell Sci 117(Pt 18):4055-4066. https://doi.org/10.1242/jcs.01275

37. Haynes CM, Petrova K, Benedetti C, Yang Y, Ron D (2007) ClpP mediates activation of a mitochondrial unfolded protein response in C. elegans. Dev Cell 13(4):467-480. https://doi.org/10.1016/j. devcel.2007.07.016

38. Haynes CM, Yang Y, Blais SP, Neubert TA, Ron D (2010) The matrix peptide exporter HAF-1 signals a mitochondrial UPR by activating the transcription factor ZC376.7 in C. elegans. Mole Cell 37(4):529-540. https://doi.org/10.1016/j.molcel.2010.01. 015

39. Nargund AM, Pellegrino MW, Fiorese CJ, Baker BM, Haynes CM (2012) Mitochondrial import efficiency of ATFS-1 regulates mitochondrial UPR activation. Science 337(6094):587-590. https://doi.org/10.1126/science. 1223560

40. Nargund AM, Fiorese CJ, Pellegrino MW, Deng P, Haynes CM (2015) Mitochondrial and nuclear accumulation of the transcription factor ATFS-1 promotes OXPHOS recovery during the UPR(mt). Mol Cell 58(1):123-133. https://doi.org/10.1016/j. molcel.2015.02.008

41. Pellegrino MW, Nargund AM, Kirienko NV, Gillis R, Fiorese CJ, Haynes CM (2014) Mitochondrial UPR-regulated innate immunity provides resistance to pathogen infection. Nature 516(7531):414-417. https://doi.org/10.1038/nature13818

42. Baker BM, Nargund AM, Sun T, Haynes CM (2012) Protective coupling of mitochondrial function and protein synthesis via the 
eIF2alpha kinase GCN-2. PLoS Genet 8(6):e1002760. https:// doi.org/10.1371/journal.pgen.1002760

43. Monaghan RM, Barnes RG, Fisher K, Andreou T, Rooney N, Poulin GB, Whitmarsh AJ (2015) A nuclear role for the respiratory enzyme CLK-1 in regulating mitochondrial stress responses and longevity. Nat Cell Biol 17(6):782-792. https://doi.org/10. 1038/ncb3170

44. Herholz M, Cepeda E, Baumann L, Kukat A, Hermeling J, Maciej S, Szczepanowska K, Pavlenko V, Frommolt P, Trifunovic A (2019) KLF-1 orchestrates a xenobiotic detoxification program essential for longevity of mitochondrial mutants. Nat Commun 10(1):3323. https://doi.org/10.1038/s41467-019-11275-w

45. Owusu-Ansah E, Yavari A, Mandal S, Banerjee U (2008) Distinct mitochondrial retrograde signals control the G1-S cell cycle checkpoint. Nat Genet 40(3):356-361. https://doi.org/10.1038/ ng. 2007.50

46. Owusu-Ansah E, Song W, Perrimon N (2013) Muscle mitohormesis promotes longevity via systemic repression of insulin signaling. Cell 155(3):699-712. https://doi.org/10.1016/j.cell. 2013.09.021

47. Ron D, Walter P (2007) Signal integration in the endoplasmic reticulum unfolded protein response. Nat Rev Mol Cell Biol 8(7):519-529. https://doi.org/10.1038/nrm2199

48. Fiorese CJ, Schulz AM, Lin YF, Rosin N, Pellegrino MW, Haynes CM (2016) The transcription factor ATF5 mediates a mammalian mitochondrial UPR. Curr Biol 26(15):2037-2043. https://doi.org/10.1016/j.cub.2016.06.002

49. Mouchiroud L, Houtkooper RH, Moullan N, Katsyuba E, Ryu D, Cantó C, Mottis A, Jo Y-S, Viswanathan M, Schoonjans K (2013) The NAD+/sirtuin pathway modulates longevity through activation of mitochondrial UPR and FOXO signaling. Cell 154(2):430-441

50. Pakos-Zebrucka K, Koryga I, Mnich K, Ljujic M, Samali A, Gorman AM (2016) The integrated stress response. EMBO Rep 17(10):1374-1395

51. Rath E, Berger E, Messlik A, Nunes T, Liu B, Kim SC, Hoogenraad N, Sans M, Sartor RB, Haller D (2012) Induction of dsRNAactivated protein kinase links mitochondrial unfolded protein response to the pathogenesis of intestinal inflammation. Gut 61(9):1269-1278. https://doi.org/10.1136/gutjnl-2011-300767

52. Taylor SS, Haste NM, Ghosh G (2005) PKR and eIF2alpha: integration of kinase dimerization, activation, and substrate docking. Cell 122(6):823-825. https://doi.org/10.1016/j.cell.2005.09.007

53. Dever TE, Feng L, Wek RC, Cigan AM, Donahue TF, Hinnebusch AG (1992) Phosphorylation of initiation factor $2 \alpha$ by protein kinase GCN2 mediates gene-specific translational control of GCN4 in yeast. Cell 68(3):585-596

54. Harding HP, Zhang Y, Ron D (1999) Protein translation and folding are coupled by an endoplasmic-reticulum-resident kinase. Nature 397(6716):271-274. https://doi.org/10.1038/16729

55. Zhan K, Vattem KM, Bauer BN, Dever TE, Chen J-J, Wek RC (2002) Phosphorylation of eukaryotic initiation factor 2 by hemeregulated inhibitor kinase-related protein kinases in Schizosaccharomyces pombe is important for resistance to environmental stresses. Mol Cell Biol 22(20):7134-7146

56. Costa-Mattioli M, Walter P (2020) The integrated stress response: From mechanism to disease. Science 368(6489):10-23. https://doi.org/10.1126/science.aat5314

57. Harding HP, Novoa I, Zhang Y, Zeng H, Wek R, Schapira M, Ron D (2000) Regulated translation initiation controls stress-induced gene expression in mammalian cells. Mol Cell 6(5):1099-1108. https://doi.org/10.1016/s1097-2765(00)00108-8

58. Fessler E, Eckl EM, Schmitt S, Mancilla IA, Meyer-Bender MF, Hanf M, Philippou-Massier J, Krebs S, Zischka H, Jae LT (2020) A pathway coordinated by DELE1 relays mitochondrial stress to the cytosol. Nature 579(7799):433-437. https://doi.org/10.1038/ s41586-020-2076-4

59. Guo X, Aviles G, Liu Y, Tian R, Unger BA, Lin YT, Wiita AP, Xu K, Correia MA, Kampmann M (2020) Mitochondrial stress is relayed to the cytosol by an OMA1-DELE1-HRI pathway. Nature 579(7799):427-432. https://doi.org/10.1038/s41586-020-2078-2

60. Zhou D, Palam LR, Jiang L, Narasimhan J, Staschke KA, Wek RC (2008) Phosphorylation of eIF2 directs ATF5 translational control in response to diverse stress conditions. J Biol Chem 283(11):7064-7073

61. Khan NA, Nikkanen J, Yatsuga S, Jackson C, Wang L, Pradhan S, Kivela R, Pessia A, Velagapudi V, Suomalainen A (2017) mTORC1 regulates mitochondrial integrated stress response and mitochondrial myopathy progression. Cell Metab 26(2):419-428. e415. https://doi.org/10.1016/j.cmet.2017.07.007

62. Cardamone MD, Tanasa B, Cederquist CT, Huang J, Mahdaviani K, Li W, Rosenfeld MG, Liesa M, Perissi V (2018) Mitochondrial retrograde signaling in mammals is mediated by the transcriptional cofactor GPS2 via direct mitochondria-to-nucleus translocation. Mol Cell 69(5):757-772.e757. https://doi.org/10. 1016/j.molcel.2018.01.037

63. Seiferling D, Szczepanowska K, Becker C, Senft K, Hermans S, Maiti P, König T, Kukat A, Trifunovic A (2016) Loss of CLPP alleviates mitochondrial cardiomyopathy without affecting the mammalian UPR mt. EMBO Rep 17(7):953-964

64. Dogan SA, Pujol C, Maiti P, Kukat A, Wang S, Hermans S, Senft K, Wibom R, Rugarli EI, Trifunovic A (2014) Tissuespecific loss of DARS2 activates stress responses independently of respiratory chain deficiency in the heart. Cell Metab 19(3):458-469. https://doi.org/10.1016/j.cmet.2014.02.004

65. Gomes AP, Price NL, Ling AJ, Moslehi JJ, Montgomery MK, Rajman L, White JP, Teodoro JS, Wrann CD, Hubbard BP, Mercken EM, Palmeira CM, de Cabo R, Rolo AP, Turner N, Bell EL, Sinclair DA (2013) Declining NAD(+) induces a pseudohypoxic state disrupting nuclear-mitochondrial communication during aging. Cell 155(7):1624-1638. https://doi.org/10.1016/j. cell.2013.11.037

66. Haas RH (2019) Mitochondrial dysfunction in aging and diseases of aging. Multidisciplinary Digital Publishing Institute, Basel

67. Durieux J, Wolff S, Dillin A (2011) The cell-non-autonomous nature of electron transport chain-mediated longevity. Cell 144(1):79-91. https://doi.org/10.1016/j.cell.2010.12.016

68. Wang Y, Hekimi S (2015) Mitochondrial dysfunction and longevity in animals: untangling the knot. Science 350(6265):12041207. https://doi.org/10.1126/science.aac4357

69. Pirinen E, Canto C, Jo YS, Morato L, Zhang H, Menzies KJ, Williams EG, Mouchiroud L, Moullan N, Hagberg C, Li W, Timmers S, Imhof R, Verbeek J, Pujol A, van Loon B, Viscomi C, Zeviani M, Schrauwen P, Sauve AA, Schoonjans K, Auwerx J (2014) Pharmacological Inhibition of poly(ADP-ribose) polymerases improves fitness and mitochondrial function in skeletal muscle. Cell Metab 19(6):1034-1041. https://doi.org/10.1016/j. cmet.2014.04.002

70. Tian Y, Garcia G, Bian Q, Steffen KK, Joe L, Wolff S, Meyer BJ, Dillin A (2016) Mitochondrial stress induces chromatin reorganization to promote longevity and UPR(mt). Cell 165(5):11971208. https://doi.org/10.1016/j.cell.2016.04.011

71. Lee SJ, Hwang AB, Kenyon C (2010) Inhibition of respiration extends $\mathrm{C}$. elegans life span via reactive oxygen species that increase HIF-1 activity. Curr Biol 20(23):2131-2136. https:// doi.org/10.1016/j.cub.2010.10.057

72. Trifunovic A, Hansson A, Wredenberg A, Rovio AT, Dufour E, Khvorostov I, Spelbrink JN, Wibom R, Jacobs HT, Larsson NG (2005) Somatic mtDNA mutations cause aging phenotypes without affecting reactive oxygen species production. Proc Natl 
Acad Sci USA 102(50):17993-17998. https://doi.org/10.1073/ pnas.0508886102

73. Wang SF, Chen MS, Chou YC, Ueng YF, Yin PH, Yeh TS, Lee HC (2016) Mitochondrial dysfunction enhances cisplatin resistance in human gastric cancer cells via the ROS-activated GCN2eIF2alpha-ATF4-xCT pathway. Oncotarget 7(45):74132-74151. https://doi.org/10.18632/oncotarget.12356

74. Nagasawa I, Kunimasa K, Tsukahara S, Tomida A (2017) BRAFmutated cells activate GCN2-mediated integrated stress response as a cytoprotective mechanism in response to vemurafenib. Biochem Biophys Res Commun 482(4):1491-1497

75. Ishihara $S$, Yasuda $M$, Ishizu A, Ishikawa $M$, Shirato $H$, Haga $H$ (2015) Activating transcription factor 5 enhances radioresistance and malignancy in cancer cells. Oncotarget 6(7):4602-4614. https://doi.org/10.18632/oncotarget.2912

76. Sheng Z, Li L, Zhu LJ, Smith TW, Demers A, Ross AH, Moser RP, Green MR (2010) A genome-wide RNA interference screen reveals an essential CREB3L2-ATF5-MCL1 survival pathway in malignant glioma with therapeutic implications. Nat Med 16(6):671-677. https://doi.org/10.1038/nm.2158

77. Sorge S, Theelke J, Yildirim K, Hertenstein H, McMullen E, Muller S, Altburger C, Schirmeier S, Lohmann I (2020) ATF4induced warburg metabolism drives over-proliferation in drosophila. Cell Rep 31(7):107659. https://doi.org/10.1016/j.celrep. 2020.107659

78. Cartoni R, Arnaud E, Médard J-J, Poirot O, Courvoisier DS, Chrast R, Martinou J-C (2010) Expression of mitofusin 2R94Q in a transgenic mouse leads to Charcot-Marie-Tooth neuropathy type 2A. Brain 133(5):1460-1469. https://doi.org/10.1093/ brain/awq082

79. van der Bliek AM (2009) Fussy mitochondria fuse in response to stress. EMBO J 28(11):1533-1534. https://doi.org/10.1038/ emboj.2009.130

80. Toyama EQ, Herzig S, Courchet J, Lewis TL, Losón OC, Hellberg K, Young NP, Chen H, Polleux F, Chan DC (2016) AMP-activated protein kinase mediates mitochondrial fission in response to energy stress. Science 351(6270):275-281

81. Rambold AS, Kostelecky B, Elia N, Lippincott-Schwartz J (2011) Tubular network formation protects mitochondria from autophagosomal degradation during nutrient starvation. Proc Natl Acad Sci USA 108(25):10190-10195. https://doi.org/10. 1073/pnas.1107402108

82. Lee J-Y, Kapur M, Li M, Choi M-C, Choi S, Kim H-J, Kim I, Lee E, Taylor JP, Yao T-P (2014) MFN1 deacetylation activates adaptive mitochondrial fusion and protects metabolically challenged mitochondria. J Cell Sci 127(22):4954-4963

83. Gomes LC, Di Benedetto G, Scorrano L (2011) During autophagy mitochondria elongate, are spared from degradation and sustain cell viability. Nat Cell Biol 13(5):589-598. https://doi.org/10.1038/ncb2220

84. Chen Y, Csordás G, Jowdy C, Schneider TG, Csordás N, Wang W, Liu Y, Kohlhaas M, Meiser M, Bergem S (2012) Mitofusin 2-containing mitochondrial-reticular microdomains direct rapid cardiomyocyte bioenergetic responses via interorganelle Ca2+ crosstalk. Circ Res 111(7):863-875

85. Chen H, Vermulst M, Wang YE, Chomyn A, Prolla TA, McCaffery JM, Chan DC (2010) Mitochondrial fusion is required for mtDNA stability in skeletal muscle and tolerance of mtDNA mutations. Cell 141(2):280-289

86. Cogliati S, Frezza C, Soriano ME, Varanita T, QuintanaCabrera R, Corrado M, Cipolat S, Costa V, Casarin A, Gomes LC (2013) Mitochondrial cristae shape determines respiratory chain supercomplexes assembly and respiratory efficiency. Cell 155(1):160-171

87. Twig G, Elorza A, Molina AJ, Mohamed H, Wikstrom JD, Walzer G, Stiles L, Haigh SE, Katz S, Las G (2008) Fission and selective fusion govern mitochondrial segregation and elimination by autophagy. EMBO J 27(2):433-446

88. Olichon A, Baricault L, Gas N, Guillou E, Valette A, Belenguer P, Lenaers G (2003) Loss of OPA1 perturbates the mitochondrial inner membrane structure and integrity, leading to cytochrome $\mathrm{c}$ release and apoptosis. J Biol Chem 278(10):7743-7746

89. Weaver D, Eisner V, Liu X, Várnai P, Hunyady L, Gross A, Hajnóczky G (2014) Distribution and apoptotic function of outer membrane proteins depend on mitochondrial fusion. Mol Cell 54(5):870-878

90. Kageyama Y, Zhang Z, Roda R, Fukaya M, Wakabayashi J, Wakabayashi N, Kensler TW, Reddy PH, Iijima M, Sesaki H (2012) Mitochondrial division ensures the survival of postmitotic neurons by suppressing oxidative damage. J Cell Biol 197(4):535-551

91. Tang S, Le PK, Tse S, Wallace DC, Huang T (2009) Heterozygous mutation of Opa1 in drosophila shortens lifespan mediated through increased reactive oxygen species production. PLoS ONE 4(2):e4492

92. Santel A, Frank S, Gaume B, Herrler M, Youle RJ, Fuller MT (2003) Mitofusin-1 protein is a generally expressed mediator of mitochondrial fusion in mammalian cells. J Cell Sci 116(Pt 13):2763-2774

93. Santel A, Fuller MT (2001) Control of mitochondrial morphology by a human mitofusin. J Cell Sci 114(Pt 5):867-874

94. Chen H, Detmer SA, Ewald AJ, Griffin EE, Fraser SE, Chan DC (2003) Mitofusins Mfn1 and Mfn2 coordinately regulate mitochondrial fusion and are essential for embryonic development. J Cell biol 160(2):189-200

95. Chen H, McCaffery JM, Chan DC (2007) Mitochondrial fusion protects against neurodegeneration in the cerebellum. Cell 130(3):548-562

96. Pham AH, Meng S, Chu QN, Chan DC (2012) Loss of Mfn2 results in progressive, retrograde degeneration of dopaminergic neurons in the nigrostriatal circuit. Hum Mol Genet 21(22):4817-4826

97. Griparic L, van der Wel NN, Orozco IJ, Peters PJ, van der Bliek AM (2004) Loss of the intermembrane space protein Mgm1/ OPA1 induces swelling and localized constrictions along the lengths of mitochondria. J Biol Chem 279(18):18792-18798

98. Cipolat S, Martins de Brito O, Dal Zilio B, Scorrano L (2004) OPA1 requires mitofusin 1 to promote mitochondrial fusion. Proc Natl Acad Sci USA 101(45):15927-15932

99. Song Z, Chen H, Fiket M, Alexander C, Chan DC (2007) OPA1 processing controls mitochondrial fusion and is regulated by mRNA splicing, membrane potential, and Yme1L. J Cell Biol 178(5):749-755

100. Frezza C, Cipolat S, Martins de Brito O, Micaroni M, Beznoussenko GV, Rudka T, Bartoli D, Polishuck RS, Danial NN, De Strooper B, Scorrano L (2006) OPA1 controls apoptotic cristae remodeling independently from mitochondrial fusion. Cell 126(1):177-189. https://doi.org/10.1016/j.cell.2006.06.025

101. Yamaguchi R, Lartigue L, Perkins G, Scott RT, Dixit A, Kushnareva Y, Kuwana T, Ellisman MH, Newmeyer DD (2008) Opa1-mediated cristae opening is Bax/Bak and BH3 dependent, required for apoptosis, and independent of Bak oligomerization. Mol Cell 31(4):557-569

102. Ehses S, Raschke I, Mancuso G, Bernacchia A, Geimer S, Tondera D, Martinou J-C, Westermann B, Rugarli EI, Langer $\mathrm{T}$ (2009) Regulation of OPA1 processing and mitochondrial fusion by m-AAA protease isoenzymes and OMA1. J Cell Biol 187(7):1023-1036

103. Head B, Griparic L, Amiri M, Gandre-Babbe S, van der Bliek AM (2009) Inducible proteolytic inactivation of OPA1 
mediated by the OMA1 protease in mammalian cells. J Cell Biol 187(7):959-966

104. Anand R, Wai T, Baker MJ, Kladt N, Schauss AC, Rugarli E, Langer T (2014) The i-AAA protease YME1L and OMA1 cleave OPA1 to balance mitochondrial fusion and fission. $\mathrm{J}$ Cell Biol 204(6):919-929

105. Griparic L, Kanazawa T, van der Bliek AM (2007) Regulation of the mitochondrial dynamin-like protein Opa1 by proteolytic cleavage. J Cell Biol 178(5):757-764

106. Mishra P, Carelli V, Manfredi G, Chan DC (2014) Proteolytic cleavage of Opa1 stimulates mitochondrial inner membrane fusion and couples fusion to oxidative phosphorylation. Cell Metab 19(4):630-641. https://doi.org/10.1016/j.cmet.2014.03. 011

107. Ishihara N, Fujita Y, Oka T, Mihara K (2006) Regulation of mitochondrial morphology through proteolytic cleavage of OPA1. EMBO J 25(13):2966-2977

108. Marelli C, Amati-Bonneau P, Reynier P, Layet V, Layet A, Stevanin G, Brissaud E, Bonneau D, Durr A, Brice A (2011) Heterozygous OPA1 mutations in Behr syndrome. Brain 134(4):e169

109. Smirnova E, Griparic L, Shurland D-L, Van Der Bliek AM (2001) Dynamin-related protein Drp1 is required for mitochondrial division in mammalian cells. Mol Biol Cell 12(8):2245-2256

110. Otera H, Wang C, Cleland MM, Setoguchi K, Yokota S, Youle RJ, Mihara K (2010) Mff is an essential factor for mitochondrial recruitment of Drp1 during mitochondrial fission in mammalian cells. J Cell Biol 191(6):1141-1158

111. Yu T, Fox RJ, Burwell LS, Yoon Y (2005) Regulation of mitochondrial fission and apoptosis by the mitochondrial outer membrane protein hFis1. J Cell Sci 118(18):4141-4151

112. Losón OC, Song Z, Chen H, Chan DC (2013) Fis1, Mff, MiD49, and MiD51 mediate Drp1 recruitment in mitochondrial fission. Mol Biol Cell 24(5):659-667

113. Yu R, Jin SB, Lendahl U, Nistér M, Zhao J (2019) Human Fis1 regulates mitochondrial dynamics through inhibition of the fusion machinery. EMBO J 38(8):12-23

114. Ferguson SM, De Camilli P (2012) Dynamin, a membraneremodelling GTPase. Nat Rev Mol Cell Biol 13(2):75-88

115. Taguchi N, Ishihara N, Jofuku A, Oka T, Mihara K (2007) Mitotic phosphorylation of dynamin-related GTPase Drp1 participates in mitochondrial fission. J Biol Chem 282(15):11521-11529

116. Chang C-R, Blackstone C (2007) Cyclic AMP-dependent protein kinase phosphorylation of Drp1 regulates its GTPase activity and mitochondrial morphology. J Biol Chem 282(30):21583-21587

117. Cribbs JT, Strack S (2007) Reversible phosphorylation of Drp1 by cyclic AMP-dependent protein kinase and calcineurin regulates mitochondrial fission and cell death. EMBO Rep 8(10):939-944. https://doi.org/10.1038/sj.embor.7401062

118. Serasinghe MN, Wieder SY, Renault TT, Elkholi R, Asciolla JJ, Yao JL, Jabado O, Hoehn K, Kageyama Y, Sesaki H, Chipuk JE (2015) Mitochondrial division is requisite to RAS-induced transformation and targeted by oncogenic MAPK pathway inhibitors. Mol Cell 57(3):521-536

119. Kashatus DF, Lim K-H, Brady DC, Pershing NL, Cox AD, Counter CM (2011) RALA and RALBP1 regulate mitochondrial fission at mitosis. Nat Cell Biol 13(9):1108

120. Ishihara N, Nomura M, Jofuku A, Kato H, Suzuki SO, Masuda K, Otera H, Nakanishi Y, Nonaka I, Goto Y-I, Taguchi N, Morinaga H, Maeda M, Takayanagi R, Yokota S, Mihara K (2009) Mitochondrial fission factor Drp1 is essential for embryonic development and synapse formation in mice. Nat Cell Biol 11(8):958-966
121. Wakabayashi J, Zhang Z, Wakabayashi N, Tamura Y, Fukaya M, Kensler TW, Iijima M, Sesaki H (2009) The dynamin-related GTPase Drp1 is required for embryonic and brain development in mice. J Cell Biol 186(6):805-816

122. Rehman J, Zhang HJ, Toth PT, Zhang Y, Marsboom G, Hong Z, Salgia R, Husain AN, Wietholt C, Archer SL (2012) Inhibition of mitochondrial fission prevents cell cycle progression in lung cancer. Faseb J 26(5):2175-2186

123. Tanwar DK, Parker DJ, Gupta P, Spurlock B, Alvarez RD, Basu MK, Mitra K (2016) Crosstalk between the mitochondrial fission protein, Drp1, and the cell cycle is identified across various cancer types and can impact survival of epithelial ovarian cancer patients. Oncotarget 7(37):60021-60037

124. Manczak M, Calkins MJ, Reddy PH (2011) Impaired mitochondrial dynamics and abnormal interaction of amyloid beta with mitochondrial protein Drp1 in neurons from patients with Alzheimer's disease: implications for neuronal damage. Hum Mol Genet 20(13):2495-2509

125. Shirendeb U, Reddy AP, Manczak M, Calkins MJ, Mao P, Tagle DA, Reddy PH (2011) Abnormal mitochondrial dynamics, mitochondrial loss and mutant huntingtin oligomers in Huntington's disease: implications for selective neuronal damage. Hum Mol Genet 20(7):1438-1455

126. Corrado M, Scorrano L (2012) Campello S (2012) Mitochondrial dynamics in cancer and neurodegenerative and neuroinflammatory diseases. Internat J Cell Biol 10(123):140-156

127. Cuervo AM (2004) Autophagy: in sickness and in health. Trends Cell Biol 14(2):70-77

128. Boya P, Reggiori F, Codogno P (2013) Emerging regulation and functions of autophagy. Nat Cell Biol 15(7):713-720

129. Gong G, Song M, Csordas G, Kelly DP, Matkovich SJ, Dorn GW 2nd (2015) Parkin-mediated mitophagy directs perinatal cardiac metabolic maturation in mice. Science (New York, NY) 350(6265): 2459

130. Takeshige K, Baba M, Tsuboi S, Noda T, Ohsumi Y (1992) Autophagy in yeast demonstrated with proteinase-deficient mutants and conditions for its induction. J Cell Biol 119(2):301-311

131. Rodriguez-Enriquez S, Kim I, Currin RT, Lemasters JJ (2006) Tracker dyes to probe mitochondrial autophagy (mitophagy) in rat hepatocytes. Autophagy 2(1):39-46

132. Zhang J, Randall MS, Loyd MR, Dorsey FC, Kundu M, Cleveland JL, Ney PA (2009) Mitochondrial clearance is regulated by Atg7-dependent and-independent mechanisms during reticulocyte maturation. Blood 114(1):157-164

133. Kundu M, Lindsten T, Yang C-Y, Wu J, Zhao F, Zhang J, Selak MA, Ney PA, Thompson CB (2008) Ulk1 plays a critical role in the autophagic clearance of mitochondria and ribosomes during reticulocyte maturation. Blood 112(4):1493-1502

134. Liu L, Feng D, Chen G, Chen M, Zheng Q, Song P, Ma Q, Zhu C, Wang R, Qi W (2012) Mitochondrial outer-membrane protein FUNDC1 mediates hypoxia-induced mitophagy in mammalian cells. Nat Cell Biol 14(2):177

135. McWilliams TG, Prescott AR, Montava-Garriga L, Ball G, Singh F, Barini E, Muqit MMK, Brooks SP, Ganley IG (2018) Basal mitophagy occurs independently of PINK1 in mouse tissues of high metabolic demand. Cell Metab 27(2):439-449.e435

136. Glick D, Zhang W, Beaton M, Marsboom G, Gruber M, Simon MC, Hart J, Dorn GW 2nd, Brady MJ, Macleod KF (2012) $\mathrm{BNip} 3$ regulates mitochondrial function and lipid metabolism in the liver. Mol Cell Biol 32(13):2570-2584

137. Schweers RL, Zhang J, Randall MS, Loyd MR, Li W, Dorsey FC, Kundu M, Opferman JT, Cleveland JL, Miller JL, Ney PA (2007) NIX is required for programmed mitochondrial clearance during reticulocyte maturation. Proc Natl Acad Sci USA 104(49):19500-19505 
138. Sandoval H, Thiagarajan P, Dasgupta SK, Schumacher A, Prchal JT, Chen M, Wang J (2008) Essential role for Nix in autophagic maturation of erythroid cells. Nature 454(7201):232-235

139. Palacino JJ, Sagi D, Goldberg MS, Krauss S, Motz C, Wacker M, Klose J, Shen J (2004) Mitochondrial dysfunction and oxidative damage in parkin-deficient mice. J Biol Chem 279(18):18614-18622

140. Park J, Lee SB, Lee S, Kim Y, Song S, Kim S, Bae E, Kim J, Shong M, Kim J-M, Chung J (2006) Mitochondrial dysfunction in Drosophila PINK1 mutants is complemented by parkin. Nature 441(7097):1157-1161

141. Shin J-H, Ko HS, Kang H, Lee Y, Lee Y-I, Pletinkova O, Troconso JC, Dawson VL, Dawson TM (2011) PARIS (ZNF746) repression of PGC-1alpha contributes to neurodegeneration in Parkinson's disease. Cell 144(5):689-702

142. Yamano K, Youle RJ (2013) PINK1 is degraded through the N-end rule pathway. Autophagy 9(11):1758-1769. https://doi. org/10.4161/auto.24633

143. Narendra D, Tanaka A, Suen D-F, Youle RJ (2008) Parkin is recruited selectively to impaired mitochondria and promotes their autophagy. J Cell Biol 183(5):795-803

144. Jin SM, Youle RJ (2013) The accumulation of misfolded proteins in the mitochondrial matrix is sensed by PINK1 to induce PARK2/Parkin-mediated mitophagy of polarized mitochondria. Autophagy 9(11):1750-1757

145. Campanella M, Seraphim A, Abeti R, Casswell E, Echave P, Duchen MR (2009) IF1, the endogenous regulator of the F1FoATPsynthase, defines mitochondrial volume fraction in HeLa cells by regulating autophagy. Biochimica et Biophysica Acta (BBA)-Bioenergetics 1787(5):393-401

146. Kim I, Lemasters JJ (2011) Mitophagy selectively degrades individual damaged mitochondria after photoirradiation. Antioxid Redox Signal 14(10):1919-1928

147. Suen D-F, Narendra DP, Tanaka A, Manfredi G, Youle RJ (2010) Parkin overexpression selects against a deleterious mtDNA mutation in heteroplasmic cybrid cells. Proc Natl Acad Sci USA 107(26):11835-11840

148. Pickrell AM, Youle RJ (2015) The roles of PINK1, parkin, and mitochondrial fidelity in Parkinson's disease. Neuron 85(2):257-273

149. Lazarou M, Jin SM, Kane LA, Youle RJ (2012) Role of PINK1 binding to the TOM complex and alternate intracellular membranes in recruitment and activation of the E3 ligase Parkin. Dev Cell 22(2):320-333

150. Sekine S, Wang C, Sideris DP, Bunker E, Zhang Z, Youle RJ (2019) Reciprocal roles of Tom7 and OMA1 during mitochondrial import and activation of PINK1. Mol Cell 73(5):1028-1043. e1025

151. Narendra DP, Jin SM, Tanaka A, Suen D-F, Gautier CA, Shen J, Cookson MR, Youle RJ (2010) PINK1 is selectively stabilized on impaired mitochondria to activate Parkin. PLoS Biol 8(1):e1000298

152. Kane LA, Lazarou M, Fogel AI, Li Y, Yamano K, Sarraf SA, Banerjee S, Youle RJ (2014) PINK1 phosphorylates ubiquitin to activate Parkin E3 ubiquitin ligase activity. J Cell Biol 205(2):143-153

153. Kondapalli C, Kazlauskaite A, Zhang N, Woodroof HI, Campbell DG, Gourlay R, Burchell L, Walden H, Macartney TJ, Deak M (2012) PINK1 is activated by mitochondrial membrane potential depolarization and stimulates Parkin E3 ligase activity by phosphorylating Serine 65. Open Biol 2(5):120080

154. Shiba-Fukushima K, Imai Y, Yoshida S, Ishihama Y, Kanao T, Sato S, Hattori N (2012) PINK1-mediated phosphorylation of the Parkin ubiquitin-like domain primes mitochondrial translocation of Parkin and regulates mitophagy. Scient Rep 2:1002
155. Kazlauskaite A, Kondapalli C, Gourlay R, Campbell DG, Ritorto MS, Hofmann K, Alessi DR, Knebel A, Trost M, Muqit MMK (2014) Parkin is activated by PINK1-dependent phosphorylation of ubiquitin at Ser65. Biochem J 460(1):127-139

156. Koyano F, Okatsu K, Kosako H, Tamura Y, Go E, Kimura M, Kimura Y, Tsuchiya H, Yoshihara H, Hirokawa T, Endo T, Fon EA, Trempe J-F, Saeki Y, Tanaka K, Matsuda N (2014) Ubiquitin is phosphorylated by PINK1 to activate parkin. Nature 510(7503):162-166

157. Schubert AF, Gladkova C, Pardon E, Wagstaff JL, Freund SM, Steyaert J, Maslen SL, Komander D (2017) Structure of PINK1 in complex with its substrate ubiquitin. Nature 552(7683):51

158. Rose CM, Isasa M, Ordureau A, Prado MA, Beausoleil SA, Jedrychowski MP, Finley DJ, Harper JW, Gygi SP (2016) Highly multiplexed quantitative mass spectrometry analysis of ubiquitylomes. Cell Syst 3(4):395-403.e394

159. Geisler S, Holmstrom KM, Skujat D, Fiesel FC, Rothfuss OC, Kahle PJ, Springer W (2010) PINK1/Parkin-mediated mitophagy is dependent on VDAC1 and p62/SQSTM1. Nat Cell Biol 12(2):119-131

160. Lazarou M, Sliter DA, Kane LA, Sarraf SA, Wang C, Burman JL, Sideris DP, Fogel AI, Youle RJ (2015) The ubiquitin kinase PINK1 recruits autophagy receptors to induce mitophagy. Nature 524(7565):309-314

161. Pickrell AM, Huang C-H, Kennedy SR, Ordureau A, Sideris DP, Hoekstra JG, Harper JW, Youle RJ (2015) Endogenous parkin preserves dopaminergic substantia nigral neurons following mitochondrial DNA mutagenic stress. Neuron 87(2):371-381

162. Kubli DA, Zhang X, Lee Y, Hanna RA, Quinsay MN, Nguyen CK, Jimenez R, Petrosyan S, Murphy AN, Gustafsson AB (2013) Parkin protein deficiency exacerbates cardiac injury and reduces survival following myocardial infarction. J Biol Chem 288(2):915-926

163. Song M, Gong G, Burelle Y, Gustafsson AB, Kitsis RN, Matkovich SJ, Dorn GW 2nd (2015) Interdependence of Parkinmediated mitophagy and mitochondrial fission in adult mouse hearts. Circ Res 117(4):346-351

164. Lee JJ, Sanchez-Martinez A, Zarate AM, Benincá C, Mayor U, Clague MJ, Whitworth AJ (2018) Basal mitophagy is widespread in Drosophila but minimally affected by loss of Pink1 or parkin. J Cell Biol 217(5):1613-1622

165. Lee SB, Kim JJ, Han S-A, Fan Y, Guo L-S, Aziz K, Nowsheen S, Kim SS, Park S-Y, Luo Q, Chung JO, Choi SI, Aziz A, Yin P, Tong S-Y, Fiesel FC, Springer W, Zhang J-S, Lou Z (2019) The AMPK-Parkin axis negatively regulates necroptosis and tumorigenesis by inhibiting the necrosome. Nat Cell Biol 21(8):940-951

166. Jacoupy M, Hamon-Keromen E, Ordureau A, Erpapazoglou Z, Coge F, Corvol JC, Nosjean O, Mannoury la Cour C, Millan MJ, Boutin JA, Harper JW, Brice A, Guedin D, Gautier CA, Corti O (2019) The PINK1 kinase-driven ubiquitin ligase Parkin promotes mitochondrial protein import through the presequence pathway in living cells. Scient Rep 9(1):11829

167. Kuroda Y, Mitsui T, Kunishige M, Shono M, Akaike M, Azuma $\mathrm{H}$, Matsumoto T (2006) Parkin enhances mitochondrial biogenesis in proliferating cells. Hum Mol Genet 15(6):883-895

168. Sliter DA, Martinez J, Hao L, Chen X, Sun N, Fischer TD, Burman JL, Li Y, Zhang Z, Narendra DP, Cai H, Borsche M, Klein C, Youle RJ (2018) Parkin and PINK1 mitigate STINGinduced inflammation. Nature 561(7722):258-262

169. Matsuda N, Sato S, Shiba K, Okatsu K, Saisho K, Gautier CA, Sou Y-S, Saiki S, Kawajiri S, Sato F, Kimura M, Komatsu M, Hattori N, Tanaka K (2010) PINK1 stabilized by mitochondrial depolarization recruits Parkin to damaged mitochondria and activates latent Parkin for mitophagy. J Cell Biol 189(2):211-221 
170. Bender A, Krishnan KJ, Morris CM, Taylor GA, Reeve AK, Perry RH, Jaros E, Hersheson JS, Betts J, Klopstock T (2006) High levels of mitochondrial DNA deletions in substantia nigra neurons in aging and Parkinson disease. Nat Genet 38(5):515

171. Kraytsberg Y, Kudryavtseva E, McKee AC, Geula C, Kowall NW, Khrapko K (2006) Mitochondrial DNA deletions are abundant and cause functional impairment in aged human substantia nigra neurons. Nat Genet 38(5):518

172. Walter J, Bolognin S, Antony PM, Nickels SL, Poovathingal SK, Salamanca L, Magni S, Perfeito R, Hoel F, Qing X (2019) Neural stem cells of Parkinson's disease patients exhibit aberrant mitochondrial morphology and functionality. Stem Cell Rep 12(5):878-889

173. Zimprich A, Biskup S, Leitner P, Lichtner P, Farrer M, Lincoln S, Kachergus J, Hulihan M, Uitti RJ, Calne DB (2004) Mutations in LRRK2 cause autosomal-dominant parkinsonism with pleomorphic pathology. Neuron 44(4):601-607

174. Hsieh C-H, Shaltouki A, Gonzalez AE, Bettencourt da Cruz A, Burbulla LF, St Lawrence E, Schule B, Krainc D, Palmer TD, Wang X (2016) Functional impairment in miro degradation and mitophagy is a shared feature in familial and sporadic Parkinson's disease. Cell Stem Cell 19(6):709-724

175. Kovalchuke L, Mosharov EV, Levy OA, Greene LA (2019) Stress-induced phospho-ubiquitin formation causes parkin degradation. Scientific reports 9(1):11682

176. Schapira AHV (2011) Mitochondrial pathology in Parkinson's disease. Mt Sinai J Med 78(6):872-881

177. Batlevi Y, La Spada AR (2011) Mitochondrial autophagy in neural function, neurodegenerative disease, neuron cell death, and aging. Neurobiol Dis 43(1):46-51
178. Hayat M (2017) Autophagy: cancer, other pathologies, inflammation, immunity, infection, and aging, vol 12. Academic Press, London

179. Houtkooper RH, Mouchiroud L, Ryu D, Moullan N, Katsyuba E, Knott G, Williams RW, Auwerx J (2013) Mitonuclear protein imbalance as a conserved longevity mechanism. Nature 497(7450):451-457. https://doi.org/10.1038/nature12188

180. Ishihara N, Jofuku A, Eura Y, Mihara K (2003) Regulation of mitochondrial morphology by membrane potential, and DRP1dependent division and FZO1-dependent fusion reaction in mammalian cells. Biochem Biophys Res Commun 301(4):891-898. https://doi.org/10.1016/s0006-291x(03)00050-0

181. Burman JL, Pickles S, Wang C, Sekine S, Vargas JNS, Zhang Z, Youle AM, Nezich CL, Wu X, Hammer JA, Youle RJ (2017) Mitochondrial fission facilitates the selective mitophagy of protein aggregates. J Cell Biol 216(10):3231-3247. https://doi.org/ 10.1083/jcb.201612106

182. Han H, Tan J, Wang R, Wan H, He Y, Yan X, Guo J, Gao Q, Li J, Shang S, Chen F, Tian R, Liu W, Liao L, Tang B, Zhang Z (2020) PINK1 phosphorylates Drp 1(S616) to regulate mitophagy-independent mitochondrial dynamics. EMBO Rep 10:e48686. https:// doi.org/10.15252/embr.201948686

183. Guerreiro R, Bras J, Hardy J (2015) SnapShot: genetics of ALS and FTD. Cell 160(4):798-798.e791

Publisher's Note Springer Nature remains neutral with regard to jurisdictional claims in published maps and institutional affiliations. 